\title{
Effect of influent $\mathrm{C} / \mathrm{N}$ ratio on $\mathrm{N}_{2} \mathrm{O}$ emissions from anaerobic/anoxic/oxic biological nitrogen removal processes
}

\author{
Xu Yan ${ }^{1} \cdot$ Jiaxi Zheng ${ }^{2}$ - Yunping Han ${ }^{2} \cdot$ Jianwei Liu $^{3} \cdot$ Jianhui Sun $^{1}$
}

Received: 27 December 2016 / Accepted: 23 August 2017 /Published online: 1 September 2017

(C) Springer-Verlag GmbH Germany 2017

\begin{abstract}
The problem of producing strong greenhouse gas of nitrous oxide $\left(\mathrm{N}_{2} \mathrm{O}\right)$ from biological nitrogen removal (BNR) process in wastewater treatment plants (WWTP) has elicited great concern from various sectors. In this study, three laboratory-scale wastewater treatment systems, with influent $\mathrm{C} / \mathrm{N}$ ratios of 3.4, 5.4, and 7.5, were set up to study the effect of influent $\mathrm{C} / \mathrm{N}$ ratio on $\mathrm{N}_{2} \mathrm{O}$ generation in anaerobic/anoxic/ oxic $\left(\mathrm{A}^{2} \mathrm{O}\right)$ process. Results showed, with the increased influent $\mathrm{C} / \mathrm{N}$ ratio, $\mathrm{N}_{2} \mathrm{O}$ generation from both nitrification and denitrification process was decreased, and the $\mathrm{N}_{2} \mathrm{O}-\mathrm{N}$ conversion ratio of the process was obviously reduced from 2.23 to $0.05 \%$. Nitrification rate in oxic section was reduced, while denitrification rate in anaerobic and anoxic section was elevated and the removal efficiency of $\mathrm{COD}, \mathrm{NH}_{4}{ }^{+}-\mathrm{N}, \mathrm{TN}$, and $\mathrm{TP}$ was enhanced in different extent. As the $\mathrm{C} / \mathrm{N}$ ratio increased from 3.4 to 7.5 , activities of three key denitrifying enzymes of nitrate reductase, nitrite reductase, and nitrous oxide reductase were increased. Moreover, microorganism analysis indicated that the relative abundance of ammoniumoxidizing bacteria (AOB) and nitrite-oxidizing bacteria
\end{abstract}

Responsible editor: Gerald Thouand

Xu Yan

yanxu@htu.cn

1 School of Environment, Key Laboratory for Yellow River and Huai River Water Environment and Pollution Control, Ministry of Education, Henan Key Laboratory for Environmental Pollution Control, Henan Normal University, Xinxiang, Henan 453007, China

2 Research Center for Eco-Environmental Sciences, Chinese Academy of Sciences, Beijing 100085, China

3 Beijing Engineering Research Center of Sustainable Urban Sewage System Construction and Risk Control, Beijing University of Civil Engineering and Architecture, Beijing, China
(NOB) were positively correlated with $\mathrm{N}_{2} \mathrm{O}$ generation, which was reduced from $(8.42 \pm 3.65)$ to $(3.61 \pm 1.66) \%$ and $(10.38 \pm 4.12)$ to $(4.67 \pm 1.62) \%$, respectively. Nos $Z$ gene copy numbers of the $\mathrm{A}^{2} \mathrm{O}$ system were increased from $(1.19 \pm 0.49) \times 10^{7}$ to $(2.84 \pm 0.54) \times 10^{8}$ copies $/ \mathrm{g}$ MLSS with the influent $\mathrm{C} / \mathrm{N}$ ratio elevated from 3.4 to 7.5. Hence, appropriate influent $\mathrm{C} / \mathrm{N}$ condition of $\mathrm{A}^{2} \mathrm{O}$ process could optimize the microbial community structure that simultaneously improve treatment efficiency and decrease the $\mathrm{N}_{2} \mathrm{O}$ generation.

Keywords Biological nitrogen removal · Greenhouse gas · Nitrous oxide $\cdot \mathrm{C} / \mathrm{N}$ ratio $\cdot$ Anaerobic/anoxic/oxic process . NosZ gene

\section{Introduction}

The strong greenhouse gas nitrous oxide $\left(\mathrm{N}_{2} \mathrm{O}\right)$ is an important cause of the global greenhouse effect and ozone depletion in the stratosphere (Rodriguez-Caballero et al. 2015). The 100-year global warming potential of $\mathrm{N}_{2} \mathrm{O}$ is approximately 300 times stronger than that of carbon dioxide $\left(\mathrm{CO}_{2}\right)$, and its emission amount continuously increases at a rate of $0.25 \%$ per year (Kishida et al. 2004; Marques et al. 2016). Biological nitrogen removal (BNR) processes in wastewater treatment plants (WWTPs) are considered a significant artificial $\mathrm{N}_{2} \mathrm{O}$ emission source, as they emit $3.2 \%$ of the total anthropogenic $\mathrm{N}_{2} \mathrm{O}$ emissions globally (Kampschreur et al. 2009; Wang et al. 2016). As the phenomenon of eutrophication occurring in rivers and lakes becomes increasingly serious, the effluent quality standards (especially for nitrogen levels) for discharge wastewater become more stringent (Zhang et al. 2016a), which leads to extensive application of BNR techniques and increasing $\mathrm{N}_{2} \mathrm{O}$ generation from WWTPs. Therefore, 
studying the mechanism of $\mathrm{N}_{2} \mathrm{O}$ production and designing an effective mitigation approach to employ during BNR processes is desperately needed.

Generally, BNR involves nitrification and denitrification processes, both of which can lead to $\mathrm{N}_{2} \mathrm{O}$ generation. The autotrophic organisms, ammonium-oxidizing bacteria (AOB) and nitrite-oxidizing bacteria (NOB), predominantly perform the nitrification process, as AOB convert ammonia $\left(\mathrm{NH}_{4}{ }^{+} \mathrm{N}\right)$ to nitrite $\left(\mathrm{NO}_{2}{ }^{-}-\mathrm{N}\right)$ and $\mathrm{NOB}$ convert $\mathrm{NO}_{2}{ }^{-}-\mathrm{N}$ to nitrate $\left(\mathrm{NO}_{3}{ }^{-}-\mathrm{N}\right)\left(\mathrm{Lu}\right.$ et al. 2014). $\mathrm{NH}_{4}{ }^{+}-\mathrm{N} / \mathrm{NO}_{2}{ }^{-} \mathrm{N}$ and $\mathrm{CO}_{2}$ are the energy and carbon sources, respectively (Kampschreur et al. 2009). During this process, $\mathrm{N}_{2} \mathrm{O}$ is recognized generally as a by-product and two pathways for its generation have been found (Wei et al. 2017). One pathway is hydroxylamine oxidation. During this pathway, intermediates of biological hydroxylamine oxidation are the source for $\mathrm{N}_{2} \mathrm{O}$ generation, which is possibly participant to the obvious disbalances in nitrifier metabolic activity, or to the chemical decomposition of hydroxylamine and miscellaneous reactions of the intermediates constituted in $\mathrm{NH}_{4}{ }^{+}-\mathrm{N}$ oxidation. The other one is nitrifier denitrification, in which $\mathrm{N}_{2} \mathrm{O}$ is produced primarily from the reduction of $\mathrm{NO}_{2}^{-}-\mathrm{N}$ by AOB, especially under the environmental conditions of low dissolved oxygen (DO) or high $\mathrm{NO}_{2}{ }^{-}-\mathrm{N}$ concentrations ( $\mathrm{Lv}$ et al. 2016; Kool et al. 2010).

In the denitrification process, $\mathrm{N}_{2} \mathrm{O}$ is recognized as an obligatory intermediate. Incomplete denitrification can result in $\mathrm{N}_{2} \mathrm{O}$ generation, which can be caused by insufficient carbon source amount or improper DO conditions (Wunderlin et al. 2012; Ribera-Guardia et al. 2016). This process is performed by a physiologically diverse group of bacteria, which convert $\mathrm{NO}_{3}{ }^{-}-\mathrm{N}$ and $\mathrm{NO}_{2}{ }^{-}-\mathrm{N}$ to gaseous products of nitric oxide $(\mathrm{NO}), \mathrm{N}_{2} \mathrm{O}$, and dinitrogen $\left(\mathrm{N}_{2}\right)$ in a stepwise manner under anoxic or anaerobic conditions ( $\mathrm{Li}$ et al. 2017). In the following order, four different reductases, nitrate reductase (Nar), nitrite reductase (Nir), nitric oxide reductase (Nor), and nitrous oxide reductase (Nos), catalyze the consecutive denitrification reactions (Zhang et al. 2016b). Among them, Nos, which is encoded by the $\operatorname{nos} Z$ gene and exists in the bacterial periplasm, is closely related to $\mathrm{N}_{2} \mathrm{O}$ generation. Generally, the nos $Z$ gene is used to investigate the DNA of particular denitrification microorganisms and measure the capacity of microbes that convert $\mathrm{N}_{2} \mathrm{O}$ to $\mathrm{N}_{2}$ (Zhu and Chen 2011).

In recent years, many studies have been undertaken to identify the emissions values and generation mechanism of $\mathrm{N}_{2} \mathrm{O}$ in BNR processes at both the lab- and full-scales. A huge variation in $\mathrm{N}_{2} \mathrm{O}$ emissions data was found, with the conversion rate of $\mathrm{N}_{2} \mathrm{O}-\mathrm{N}$ widely ranging from 0 to $95 \%$ of the influent nitrogen load (Wang et al. 2016; Kampschreur et al. 2009). Several factors benefiting $\mathrm{N}_{2} \mathrm{O}$ emissions from BNR were found, such as low influent $\mathrm{C} / \mathrm{N}$ ratio (Hu et al. 2013), low pH (Hynes and Knowles 1984), short sludge retention time (SRT) (Hanaki et al. 1992), low DO concentration (Kampschreur et al. 2008), presence of toxic compounds
(Mannina et al. 2016), and carbon source shock (Wang et al. 2011b). Particularly, influent $\mathrm{C} / \mathrm{N}$ ratio is considered one of the most significant parameters because it can markedly affect the $\mathrm{N}_{2} \mathrm{O}$ emissions from both the nitrification and denitrification processes. He et al. (2016) found $\mathrm{N}_{2} \mathrm{O}$ emission at the $\mathrm{C} / \mathrm{N}$ ratio of 2 was much stronger than that at the ratios of 5 and 8 during nitrification process in a biological aerated filter reactor. In a SBR reactor, $\mathrm{N}_{2} \mathrm{O}$ emission in the condition of $\mathrm{BOD}_{5} / \mathrm{TN}$ of 2.6 was about 270 times greater than that in $\mathrm{BOD}_{5} / \mathrm{TN}$ of 4.5 (Kishida et al. 2004). During the denitrification process, the $\mathrm{N}_{2} \mathrm{O}$ conversion rate was $0.005 \%$ for optimal $\mathrm{C} / \mathrm{N}$ ratio, when the carbon source became insufficient the conversion rate increased to $0.5 \%$ (Chung and Chung 2000).

Among multiple types of BNR processes, the anaerobic/ anoxic/oxic $\left(\mathrm{A}^{2} \mathrm{O}\right)$ process is one of the most widely used (accounting for $24 \%$ of all BNR processes in WWTPs in China (Xie and Wang 2011)). Some studies have investigated $\mathrm{N}_{2} \mathrm{O}$ emissions from the full-scale WWTPs with an $\mathrm{A}^{2} \mathrm{O}$ process and identified the emission characteristics (Yan et al. 2014; Wang et al. 2011a). Ren et al. (2015) studied the direct emissions of $\mathrm{N}_{2} \mathrm{O}$ from an $\mathrm{A}^{2} \mathrm{O}$ system under different influent $\mathrm{C} / \mathrm{N}$ ratios, but the $\mathrm{N}_{2} \mathrm{O}$ generation pathway and function microorganism for this process was not illuminated (Ren et al. 2015). In fact, microbes are the functional core of wastewater treatment systems and major producers of $\mathrm{N}_{2} \mathrm{O}$ emissions. To date, few studies have focused on the effect of influent $\mathrm{C} / \mathrm{N}$ ratio on $\mathrm{N}_{2} \mathrm{O}$ generation and the functional bacterial content of $\mathrm{AOB}$ and denitrifiers for this widely implemented treatment process (Ren et al. 2015). Thorough study about the influence mechanism of influent $\mathrm{C} / \mathrm{N}$ ratio on $\mathrm{N}_{2} \mathrm{O}$ generation for $\mathrm{A}^{2} \mathrm{O}$ process was greatly needed.

The purpose of this study was to reveal the effect of influent $\mathrm{C} / \mathrm{N}$ ratio on $\mathrm{N}_{2} \mathrm{O}$ production and the related functional bacteria in the $\mathrm{A}^{2} \mathrm{O}$ treatment process. Three parallel $\mathrm{A}^{2} \mathrm{O}$ processes were set up in a laboratory with influent $\mathrm{C} / \mathrm{N}$ ratios of 3.4, 5.4, and 7.5. Under the different influent $\mathrm{C} / \mathrm{N}$ ratios, the characteristics of $\mathrm{N}_{2} \mathrm{O}$ emissions and generation, nitrification and denitrification rates, and activities of key denitrifying enzymes (Nar, Nir, and Nos) during the $\mathrm{A}^{2} \mathrm{O}$ processes were investigated. Furthermore, relative abundances of $\mathrm{AOB}$ and NOB in the oxic section were analyzed by fluorescence in situ hybridization (FISH), and gene copy numbers of nos $\mathrm{Z}$ in the anoxic section were analyzed using real-time quantitative PCR (qPCR).

\section{Materials and methods}

\section{Experimental setup and operation}

Three lab-scale $\mathrm{A}^{2} \mathrm{O}$ treatment systems were parallelly kept with the influent $\mathrm{C} / \mathrm{N}$ ratios of 3.4, 5.4, and 7.5. A schematic diagram and operating parameters of the process are shown in 
Fig. 1 Schematic diagram of the experimental equipment and process

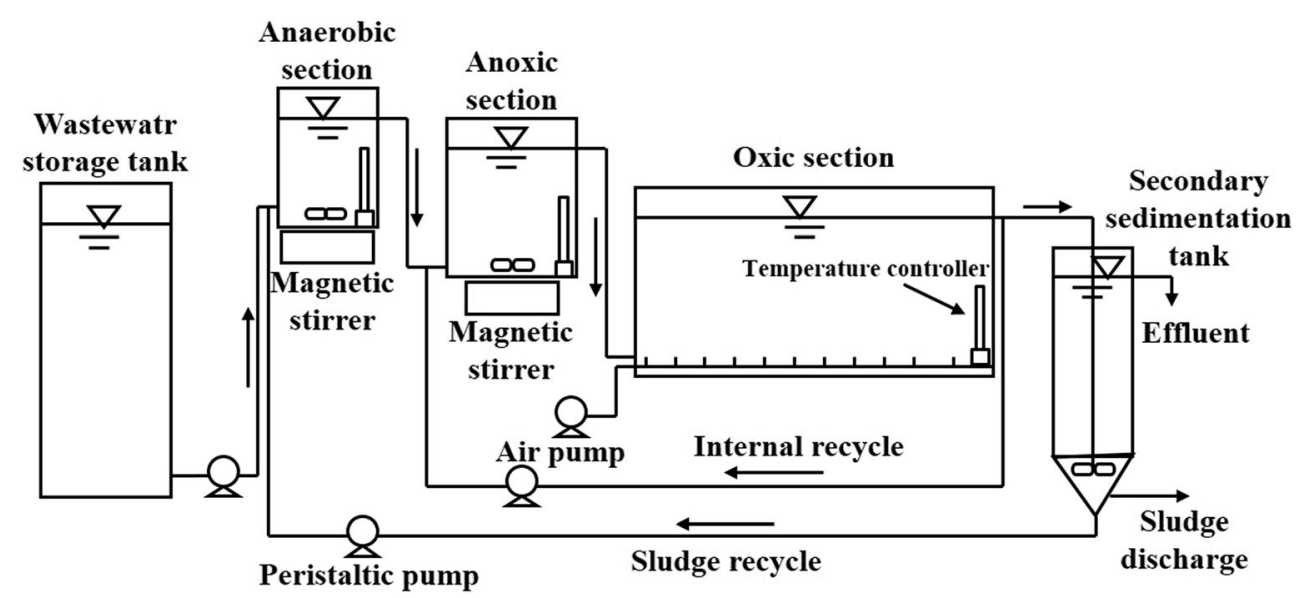

Fig. 1 and Table 1, respectively. Except for influent C/N ratio, the three parallel treatment processes were under identical operation conditions (Table 1). The hydraulic retention time (HRT) for the anaerobic tank, anoxic tank, oxic tank, and secondary sedimentation tank was $1.4,2.8,8.5$, and $1.4 \mathrm{~h}$, respectively. The seeding sludge for the treatment processes was from oxic section of the Luotuowan WWTP (Xinxiang, China).

To prevent the sedimentation of sludge in anaerobic and anoxic tanks, magnetic stirrers (85-2, Sile Shanghai) were fixed and kept with the rotational speed of $500 \mathrm{rpm}$. DO concentration in the oxic section was kept at approximately $2.0 \mathrm{mg} / \mathrm{L}$, by adjusting the aeration rate. A mechanical stirrer was fixed at the bottom of the secondary sedimentation tanks and operated at a very low rotating speed of $30 \mathrm{rpm}$ to prevent the concentrated activated sludge from forming massive flocs, which is favorable for sludge recycling. After 2 months of sludge acclimation, the treatment processes stabilized, indicated by the stable COD, $\mathrm{NH}_{4}{ }^{+}-\mathrm{N}, \mathrm{TN}$, and TP concentrations observed in the effluents. Then, gas and water samples were taken simultaneously every 3 days for 1 month. The gas samples were used to determine the $\mathrm{N}_{2} \mathrm{O}$ concentration; the details of which are described in "Analysis procedures" section. Liquid samples were used to determine water quality parameters.

Table 1 Operation parameters of parallel $\mathrm{A}^{2} \mathrm{O}$ treatment processes

\begin{tabular}{ll}
\hline Parameters & Value \\
\hline Total effective volume (L) & 50 \\
Total inflow (L/day) & 85 \\
Water temperature $\left({ }^{\circ} \mathrm{C}\right)$ & $25 \pm 1$ \\
SRT (day) & 15 \\
Mixed liquor suspended solid (MLSS) (mg/L) & $3000 \pm 200$ \\
Internal recycle ratio (\%) & 200 \\
Sludge recycle ratio (\%) & 100 \\
\hline
\end{tabular}

\section{Influent preparation}

The influent wastewater for the $\mathrm{A}^{2} \mathrm{O}$ processes was obtained from the rotational flow grit chamber of the Luotuowan WWTP. As seen in Fig. 2, the effluent quality of the rotational flow grit chamber exhibited approximately the same diurnal trend. According to the effluent quality data shown in Fig. 2, the wastewater was taken at a set time, so the $\mathrm{C} / \mathrm{N}$ ratio of the wastewater met the demand of this study. Occasionally, the $\mathrm{C} /$ $\mathrm{N}$ ratio of the obtained wastewater was far from the demanded ratio, so carbon or nitrogen sources or running water was increased to adjust the water quality. $\mathrm{CH}_{3} \mathrm{COONa} \cdot 3 \mathrm{H}_{2} \mathrm{O}$ and $\mathrm{NH}_{4} \mathrm{Cl}$ were used as carbon and nitrogen source, respectively.

\section{Sampling and analytical methods}

\section{Gas sampling of nonaerated surfaces}

For the nonaerated surfaces of anaerobic tank, anoxic tank, and secondary sedimentation tank, the sampling method was according to our previous publication (Yan et al. 2016). A closed gas-tight chamber was installed on the top of the tanks,

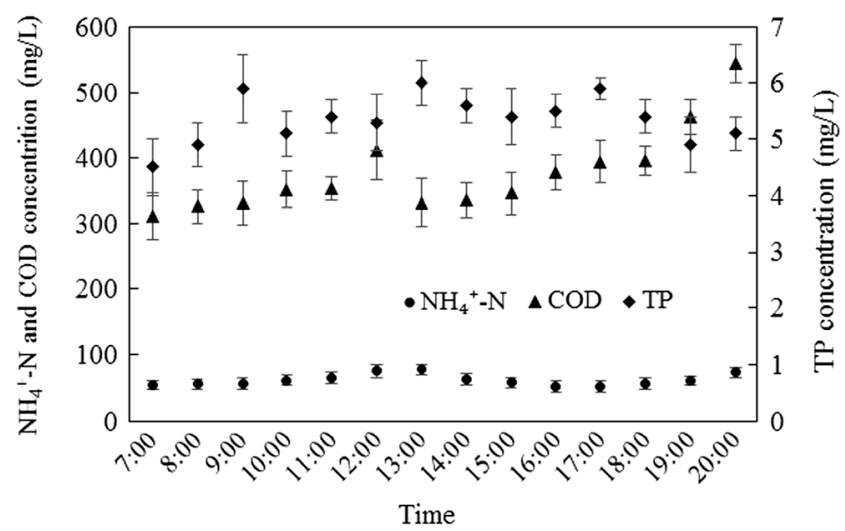

Fig. 2 Diurnal variation in effluent quality from the rotational flow grit chamber based on the data from October to December 2015 
and the air tightness was checked during each sampling event. Four gas samples were taken at $3 \mathrm{~min}$ intervals for $9 \mathrm{~min}$. Each gas sample was collected into a 50-ml sampling bag (Delin, China) through polytetrafluoroethylene tubes using a polypropylene syringe. The gas flux of the nonaerated surface was calculated by the equation:

$F=(V / A) \rho(\Delta c / \Delta t)$

where $F\left(\mathrm{mg} / \mathrm{m}^{2} \mathrm{~min}\right)$ is the gas flux, $V\left(\mathrm{~m}^{3}\right)$ is the volume of the upper-water space, $A\left(\mathrm{~m}^{2}\right)$ is the liquid surface area, $\rho(\mathrm{mg} /$ $\left.\mathrm{m}^{3}\right)$ is the concentration of $\mathrm{N}_{2} \mathrm{O}$, and $\Delta_{c}(v / \mathrm{v}) / \Delta t(\mathrm{~min})$ is the change in $\mathrm{N}_{2} \mathrm{O}$ concentration per minute during sampling time. The $\mathrm{N}_{2} \mathrm{O}$ density $(\rho)$ was calculated using the equation:

$\rho=10^{-6} M P / R T$

where $M$ is the molecular weight of $\mathrm{N}_{2} \mathrm{O}(44.02 \mathrm{~g} / \mathrm{mol}), P$ is the atmospheric pressure (1 atm), $R$ is the gas constant $(0.082 \mathrm{~L} \mathrm{~atm} / \mathrm{K} \mathrm{mol})$, and $T$ is the temperature $(\mathrm{K})$.

\section{Gas sampling of aerated surfaces}

The gas sampling method used in the oxic section was according to our recent publications (Yan et al. 2016). During the sampling period, a closed gas-tight chamber was installed on the top of the tank. The air tightness was tested during each sampling event. The effluent air was obtained through polytetrafluoroethylene tubes using a polypropylene syringe and then kept in 50-ml sampling bags. The gas flux of the aerated surface was calculated using:

$F=\rho c Q_{a} / A$

where $c(v / v)$ is the $\mathrm{N}_{2} \mathrm{O}$ concentration, $Q_{\mathrm{a}}\left(\mathrm{m}^{3} / \mathrm{min}\right)$ is the aeration intensity of air pump, and $A\left(\mathrm{~m}^{2}\right)$ is the liquid surface of the oxic tank.

\section{Dissolved gas sampling}

The detection method used for dissolved $\mathrm{N}_{2} \mathrm{O}$ in wastewater was according to Kimochi et al. (1998).

\section{Analysis procedures}

Gas $\mathrm{N}_{2} \mathrm{O}$ concentrations were analyzed using a gas chromatograph (HP-Chemistation 5890, Agilent Co. Ltd., USA), equipped with an electron capture detector (GC-ECD). The oxidation-reduction potential (ORP) of the water was measured by a WTW3110 ORP (WTW, Germany) meter. The water quality parameters of $\mathrm{COD}, \mathrm{NH}_{4}{ }^{+}-\mathrm{N}, \mathrm{NO}_{2}{ }^{-}-\mathrm{N}, \mathrm{NO}_{3}{ }^{-} \mathrm{N}, \mathrm{TN}$, and TP were measured using standard methods (CEPB 2004). COD was detected by closed reflux and colorimetric method.
Nesslerization, colorimetric method, ultraviolet spectrophotometric screening method, and persulfate method were used in the analyses of $\mathrm{NH}_{4}{ }^{+}-\mathrm{N}, \mathrm{NO}_{2}{ }^{-}-\mathrm{N}, \mathrm{NO}_{3}{ }^{-}-\mathrm{N}$, and $\mathrm{TN}$, respectively. Vanadomolybdophosphoric acid colorimetric method was adopted in TP measurement. The DO were measured by WTW-Multi 340i DO (WTW, Germany) meters. The activity detection methods of Nar, Nir, and Nor were according to our previous publication (Yan et al. 2016). The preparation of cell extracts was according to Kristjansson and Hollocher (1980).

Denitrification bacteria content was measured via qPCR based on the nosZ gene, which was performed according to our recent publication (Yan et al. 2016). The primers used in the measurement were nosZ-F 5-AGAACGACCAGCTG ATCGACA-3 and nosZ-R 5-TCCATGGTGACGCC GTGGTTG-3 (Chon et al. 2011). The distribution of functional bacteria in the oxic section under different influent $\mathrm{C} / \mathrm{N}$ ratios was monitored by the fluorescence in situ hybridization (FISH) technique with 16S rRNA-targeted oligonucleotide probes. The activated sludge flocs from the oxic section after 2 months of operation under each influent $\mathrm{C} / \mathrm{N}$ ratio were fixed with $4 \%$ paraformaldehyde at $4{ }^{\circ} \mathrm{C}$ for about $12 \mathrm{~h}$ for the FISH experiments. These fixed flocs were washed three times with phosphate-buffered saline $(\mathrm{pH} 7.2)$ and then were spotted on gelatin-coated glass slides, air-dried, and consecutively dehydrated in 50, 80, and $100 \%$ ethanol. A hybridization solution containing $5 \mathrm{ng} / \mu \mathrm{l}$ of probe was applied to the slide. Table 2 lists the oligonucleotide probes used for FISH in this study. In situ hybridization was performed at $46{ }^{\circ} \mathrm{C}$ for $3 \mathrm{~h}$. The excess probes were washed off by heating at $48^{\circ} \mathrm{C}$ for $15 \mathrm{~min}$ with washing buffer containing Tris- $\mathrm{HCl}(20 \mathrm{mM}$, $\mathrm{pH} 7.2), \mathrm{NaCl}(70 \mathrm{mM})$, EDTA $(5 \mathrm{mM})$, and SDS $(0.01 \%)$. The $\mathrm{NaCl}$ concentration was fixed by experiments. The images of the FISH were captured by confocal laser scanning microscopy (CLSM) and analyzed with LAS AF Lite software (Leica Microsystems, Inc., USA).

\section{Calculation of $\mathrm{N}_{2} \mathrm{O}$ generation}

The calculation of $\mathrm{N}_{2} \mathrm{O}$ generation amount from units of the $\mathrm{A}^{2} \mathrm{O}$ system was using Eqs. (4)-(7).

$$
\begin{aligned}
& G_{A n}=\left(E_{A n}+C_{A n} \times\left(1+R_{1}\right) Q-C_{I F} \times Q-C_{\mathrm{SST}} \times R_{1} Q\right) / Q \\
& G_{\mathrm{Ax}}=\left(E_{\mathrm{Ax}}+C_{\mathrm{Ax}} \times\left(1+R_{1}+R_{2}\right) Q-C_{A n} \times\left(1+R_{1}\right) Q-C_{\mathrm{Ox}} \times R_{2} Q\right) / Q
\end{aligned}
$$

$G_{\mathrm{Ox}}=\left(E_{\mathrm{Ox}}+C_{\mathrm{Ox}} \times\left(1+R_{1}+R_{2}\right) Q-C_{\mathrm{Ax}} \times\left(1+R_{1}+R_{2}\right) Q\right) / Q$

$G_{\mathrm{SST}}=\left(E_{\mathrm{SST}}+C_{\mathrm{SST}} \times\left(1+R_{1}\right) Q-C_{\mathrm{Ox}} \times\left(1+R_{1}\right) Q\right) / Q$

where $G_{\mathrm{An}}(\mathrm{mg} / \mathrm{L})$ is the $\mathrm{N}_{2} \mathrm{O}$ generation from anaerobic tank, $G_{\mathrm{Ax}}(\mathrm{mg} / \mathrm{L})$ is the $\mathrm{N}_{2} \mathrm{O}$ generation from anoxic tank, $G_{\mathrm{Ox}}(\mathrm{mg} /$ 
Table 2 Oligonucleotide primer, fluorescently labeled, and hybridization conditions (Zhu and Chen et al. 2011; Han et al. 2012)

\begin{tabular}{llllll}
\hline Probe & Sequence $\left(5^{\prime}-3^{\prime}\right)$ & Fluorescein & Color & Specificity & $\begin{array}{l}\text { Formamide solution } \\
\text { concentration }(\%)\end{array}$ \\
\hline EUB338 & GCTGCCTCCCGTAGGAGT & Texas Red & Red & Bacteria & 20 \\
Nit3 & CCTGTGCTCCATGCTCCG & FITC & Green & Nitrobacter spp. & 40 \\
Ntspa662 & GGAATTCCGCGCTCCTCT & FITC & & Genus Nitrospira & 40 \\
Nsr1156 & CCCGTTCTCCTGGGCAGT & FITC & & Genus Nitrospira & 30 \\
Nso190 & CGATCCCCTGCTTTTCTCC & Cy5 & Yellow & Ammonium-oxidizing $\beta$-Proteobacteria & 55 \\
Nso1225 & CGCGATTGTATTACGTGTGA & Cy5 & & Ammonium-oxidizing $\beta$-Proteobacteria & 35 \\
\hline
\end{tabular}

$\mathrm{L})$ is the $\mathrm{N}_{2} \mathrm{O}$ generation from oxic tank, and $G_{\mathrm{SST}}(\mathrm{mg} / \mathrm{L})$ is the $\mathrm{N}_{2} \mathrm{O}$ generation from secondary sedimentation tank; $E_{\mathrm{An}}(\mathrm{mg} / \mathrm{L})$ is the $\mathrm{N}_{2} \mathrm{O}$ emission from anaerobic tank, $E_{\mathrm{Ax}}(\mathrm{mg} / \mathrm{L})$ is the $\mathrm{N}_{2} \mathrm{O}$ emission from anoxic tank, $E_{\mathrm{Ox}}$ $(\mathrm{mg} / \mathrm{L})$ is the $\mathrm{N}_{2} \mathrm{O}$ emission from oxic tank, and $E_{\mathrm{SST}}$ $(\mathrm{mg} / \mathrm{L})$ is the $\mathrm{N}_{2} \mathrm{O}$ emission from secondary sedimentation tank; $C_{\mathrm{IF}}$ is the dissolved $\mathrm{N}_{2} \mathrm{O}$ concentration in influent, $C_{\mathrm{An}}(\mathrm{mg} / \mathrm{L})$ is the dissolved $\mathrm{N}_{2} \mathrm{O}$ concentration in anaerobic tank, $C_{\mathrm{Ax}}(\mathrm{mg} / \mathrm{L})$ is the dissolved $\mathrm{N}_{2} \mathrm{O}$ concentration in anoxic tank, $C_{\mathrm{Ox}}(\mathrm{mg} / \mathrm{L})$ is the dissolved $\mathrm{N}_{2} \mathrm{O}$ concentration in oxic tank, and $C_{\mathrm{SST}}(\mathrm{mg} / \mathrm{L})$ is the dissolved $\mathrm{N}_{2} \mathrm{O}$ concentration in secondary sedimentation tank; and $R_{1}$ $(\%), R_{2}(\%)$, and $Q$ (L/day) are the sludge return ratio, internal recycle ratio, and influent flow rate, respectively.

\section{Calculation of nitrification and denitrification efficiency}

In an $\mathrm{A}^{2} \mathrm{O}$ treatment process, the nitrification rate in the oxic area and the denitrification rate in both the anaerobic and anoxic areas can be calculated using Eqs. (8)-(10).

$R_{\mathrm{n}-\text { oxic }}=\frac{\left(\left[\mathrm{NH}_{4}^{+}-\mathrm{N}\right]_{\text {anoxic }}-\left[\mathrm{NH}_{4}^{+}-\mathrm{N}\right]_{\text {oxic }}\right) \cdot\left(F_{\mathrm{I}}+F_{\mathrm{IR}}+F_{\mathrm{ER}}\right)}{V_{\text {oxic }} \cdot \mathrm{VSS}_{\text {oxic }}}$

where $R_{\mathrm{n}-\mathrm{oxic}}$ (g/g volatile suspended solid (VSS) day) is the nitrification rate in the oxic area, $\left[\mathrm{NH}_{4}{ }^{+}-\mathrm{N}\right]_{\text {anoxic }}(\mathrm{mg} / \mathrm{L})$ is the $\mathrm{NH}_{4}{ }^{+}-\mathrm{N}$ concentration in the anoxic area, $\left[\mathrm{NH}_{4}{ }^{+}-\mathrm{N}\right]_{\text {oxic }}(\mathrm{mg} /$ $\mathrm{L})$ is the $\mathrm{NH}_{4}{ }^{+}-\mathrm{N}$ concentration in the oxic area, $F_{\mathrm{I}}(85 \mathrm{~L} /$ day $)$ is the influent flow, $F_{\mathrm{IR}}(170 \mathrm{~L} /$ day $)$ is the internal recycle flow, $F_{\mathrm{ER}}(85 \mathrm{~L} /$ day $)$ is the external recycle flow, $V_{\text {oxic }}(\mathrm{L})$ is the volume of the oxic area, and $V S S_{\text {oxic }}(\mathrm{mg} / \mathrm{L})$ is the VSSs in the oxic area.

$R_{\mathrm{dn}-\text { anaerobic }}=\frac{\left[\mathrm{NO}_{x}^{-}-\mathrm{N}\right]_{\text {influent }} \cdot F_{\mathrm{I}}+\left[\mathrm{NO}_{x}^{-}-\mathrm{N}\right]_{\mathrm{ER}} \cdot F_{\mathrm{ER}}-\left[\mathrm{NO}_{x}^{-}-\mathrm{N}\right]_{\text {anaerobic }} \cdot\left(F_{\mathrm{I}}+F_{\mathrm{ER}}\right)}{V_{\text {anaerobic }} \cdot V S S_{\text {anaerobic }}}$

where $R_{\mathrm{dn}-\text { anaerobic }}(\mathrm{g} / \mathrm{g}$ VSS day) is the denitrification rate in the anaerobic area, $\left[\mathrm{NO}_{\mathrm{x}}{ }^{-} \mathrm{-N}\right]_{\text {influent }}(\mathrm{mg} / \mathrm{L})$ is the sum of the $\mathrm{NO}_{3}{ }^{-}-\mathrm{N}$ and $\mathrm{NO}_{2}{ }^{-}-\mathrm{N}$ concentrations in the influent, $\left[\mathrm{NO}_{\mathrm{x}}{ }^{-}\right.$ $\mathrm{N}]_{\mathrm{ER}}(\mathrm{mg} / \mathrm{L})$ is the sum of the $\mathrm{NO}_{3}^{-}{ }^{-} \mathrm{N}$ and $\mathrm{NO}_{2}{ }^{-}-\mathrm{N}$ concentrations in the external flow, $\left[\mathrm{NO}_{\mathrm{x}}{ }^{-} \mathrm{N}\right]_{\text {anaerobic }}(\mathrm{mg} / \mathrm{L})$ is the sum of the $\mathrm{NO}_{3}{ }^{-}-\mathrm{N}$ and $\mathrm{NO}_{2}{ }^{-}-\mathrm{N}$ concentrations in the anaerobic area, $V_{\text {anaerobic }}(\mathrm{L})$ is the volume of the anaerobic area, and $\operatorname{VSS}_{\text {anaerobic }}(\mathrm{mg} / \mathrm{L})$ is the VSS concentration in the anaerobic area.

$R_{\mathrm{dn}-\text { anoxic }}=\frac{\left[\mathrm{NO}_{\mathrm{x}}^{-}-\mathrm{N}\right]_{\text {anaerobic }} \cdot\left(F_{\mathrm{I}}+F_{\mathrm{ER}}\right)+\left[\mathrm{NO}_{\mathrm{x}}^{-}-\mathrm{N}\right]_{\text {oxic }} \cdot F_{\mathrm{IR}}-\left[\mathrm{NO}_{\mathrm{x}}^{-}-\mathrm{N}\right]_{\text {anoxic }} \cdot\left(F_{\mathrm{I}}+F_{\mathrm{IR}}+F_{\mathrm{ER}}\right)}{V_{\text {anoxic }} \cdot V S S_{\text {anoxic }}}$

where $R_{\text {dn-anoxic }}(\mathrm{g} / \mathrm{g}$ VSS day) is the denitrification rate in the anoxic area, $\left[\mathrm{NO}_{\mathrm{x}}{ }^{-} \mathrm{N}\right]_{\text {oxic }}(\mathrm{mg} / \mathrm{L})$ is the sum of the $\mathrm{NO}_{3}{ }^{-}-\mathrm{N}$ and $\mathrm{NO}_{2}{ }^{-}-\mathrm{N}$ concentrations in the oxic area, $\left[\mathrm{NO}_{\mathrm{x}}{ }^{-} \mathrm{-N}\right]_{\text {anoxic }}(\mathrm{mg} / \mathrm{L})$ is the sum of the $\mathrm{NO}_{3}{ }^{-} \mathrm{N}$ and $\mathrm{NO}_{2}{ }^{-}-\mathrm{N}$ concentrations in the anoxic area, $V_{\text {anoxic }}(\mathrm{L})$ is the volume of the anoxic area, and $V S S_{\text {anoxic }}(\mathrm{mg} / \mathrm{L})$ is the VSS concentration in the anoxic area.

\section{Results and discussion}

\section{Comparison of the performance between different $\mathrm{C} / \mathrm{N}$ ratios}

The COD, $\mathrm{NH}_{4}{ }^{+}-\mathrm{N}, \mathrm{TN}, \mathrm{TP}, \mathrm{NO}_{3}{ }^{-}-\mathrm{N}$, and $\mathrm{NO}_{2}{ }^{-}-\mathrm{N}$ concentrations in each tank of the $\mathrm{A}^{2} \mathrm{O}$ treatment system under 
Fig. 3 Pollutant concentrations in each unit under different influent $\mathrm{C} / \mathrm{N}$ ratios
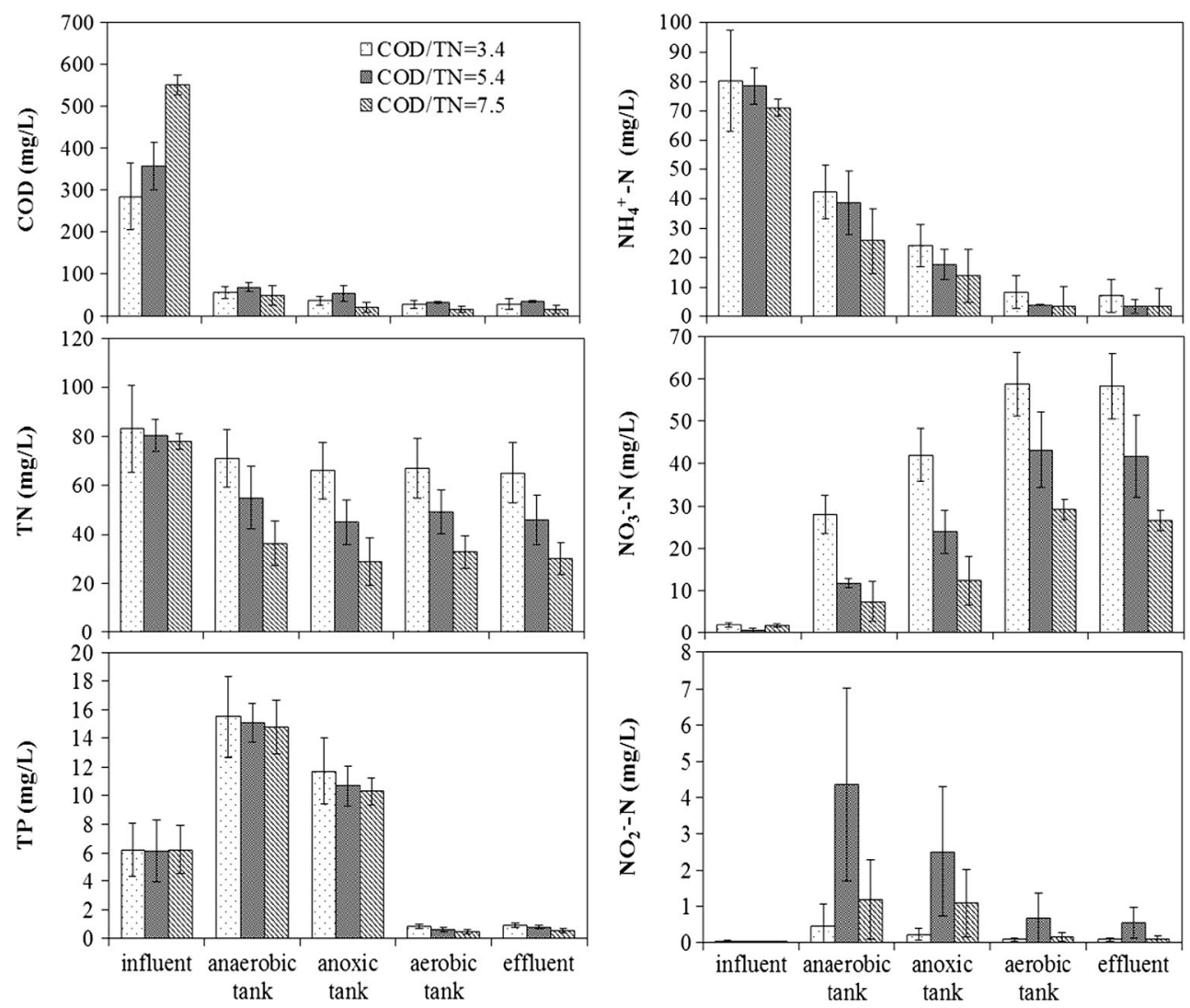

different $\mathrm{C} / \mathrm{N}$ ratios are shown in Fig. 3. High removal efficiency of COD, $\mathrm{NH}_{4}{ }^{+}-\mathrm{N}$, and TP occurred under all operation modes in this work. As the $\mathrm{C} / \mathrm{N}$ ratio increased from 3.4 to 7.5 , the TN removal efficiency increased dramatically from 21.69 to $61.56 \%$, which revealed the denitrification reactions had been enhanced. The removal rates of $\mathrm{COD}, \mathrm{NH}_{4}{ }^{+}-\mathrm{N}$, and TP were also elevated slightly. To understand better the $\mathrm{N}_{2} \mathrm{O}$ generation mechanisms in this $\mathrm{A}^{2} \mathrm{O}$ system, the ORP and DO in each unit were investigated (Fig. 3 and Table 3 ).

The changes in the influent $\mathrm{C} / \mathrm{N}$ ratio showed a marked impact on nitrogen removal. $\mathrm{As} \mathrm{NH}_{4}{ }^{+} \mathrm{N}$ concentrations in the influent were almost constant under the three operation modes, the differences in TN removal rate were caused by increased carbon source in the influent. The carbon source plays a significant role in denitrification processes, as limited biodegradable organic carbon leads to incomplete denitrification and low TN removal efficiency because of the absence of an electron donor (Chung and Chung 2000; Itokawa et al. 2001). The denitrification rates of the anaerobic and anoxic tanks under different $\mathrm{C} / \mathrm{N}$ ratios were analyzed using Eqs. (9)-(10) (Table 4). The denitrification rates in the anaerobic section were higher than those in the anoxic section under the influent $\mathrm{C} / \mathrm{N}$ ratios of 3.4 and 5.4 in this work. When the $\mathrm{C} / \mathrm{N}$ ratio was 7.5 , the available carbon source in the anoxic section increased, which led to an increase in the denitrification rate of the anoxic section. The changes in ORP in the anoxic section also reflected that the denitrification had been promoted with increased COD in the influent (Table 3). However, the indication of this result was not the $\mathrm{NO}_{\mathrm{x}}{ }^{-} \mathrm{N}$ removal mainly processed in the anaerobic section. The $\mathrm{NO}_{\mathrm{x}}{ }^{-}-\mathrm{N}$ removal amount was decided mainly by the

Table 3 ORP and DO in anaerobic, anoxic, and oxic section under different influent $\mathrm{C} / \mathrm{N}$ ratios

\begin{tabular}{|c|c|c|c|c|c|c|c|c|}
\hline \multicolumn{5}{|l|}{ ORP (mV) } & \multicolumn{4}{|l|}{$\mathrm{DO}(\mathrm{mg} / \mathrm{L})$} \\
\hline & $\begin{array}{l}\text { Anaerobic } \\
\text { section }\end{array}$ & Anoxic section & Oxic section & $\begin{array}{l}\text { Secondary } \\
\text { sedimentation tank }\end{array}$ & $\begin{array}{l}\text { Anaerobic } \\
\text { section }\end{array}$ & $\begin{array}{l}\text { Anoxic } \\
\text { section }\end{array}$ & $\begin{array}{l}\text { Oxic } \\
\text { section }\end{array}$ & $\begin{array}{l}\text { Secondary } \\
\text { sedimentation tank }\end{array}$ \\
\hline $\mathrm{C} / \mathrm{N}=3.4$ & $-185.28 \pm 32.96$ & $-23.60 \pm 64.47$ & $161.90 \pm 29.92$ & $10.32 \pm 18.84$ & $0.20 \pm 0.03$ & $0.27 \pm 0.05$ & $2.01 \pm 0.15$ & $0.52 \pm 0.11$ \\
\hline $\mathrm{C} / \mathrm{N}=5.4$ & $-195.43 \pm 92.73$ & $-99.91 \pm 27.60$ & $86.91 \pm 33.24$ & $-16.46 \pm 14.22$ & $0.17 \pm 0.02$ & $0.25 \pm 0.02$ & $2.03 \pm 0.17$ & $0.47 \pm 0.15$ \\
\hline $\mathrm{C} / \mathrm{N}=7.5$ & $-226.26 \pm 42.66$ & $-147.08 \pm 44.60$ & $51.98 \pm 15.28$ & $-22.76 \pm 10.60$ & $0.16 \pm 0.02$ & $0.24 \pm 0.03$ & $1.98 \pm 0.12$ & $0.48 \pm 0.08$ \\
\hline
\end{tabular}


Table 4 Nitrification rate in oxic section and denitrification rate in anaerobic and anoxic section under different influent $\mathrm{C} / \mathrm{N}$ ratio

\begin{tabular}{llll}
\hline $\begin{array}{l}\text { Nitrification rate } \\
\text { in oxic section } \\
\left(\mathrm{mg} \mathrm{NH}_{4}{ }^{+}-\mathrm{N} / \mathrm{g}\right.\end{array}$ & $\begin{array}{l}\text { Denitrification rate } \\
\text { in anaerobic section } \\
\left(\mathrm{mg} \mathrm{NO}_{x}{ }^{-}-\mathrm{N} / \mathrm{g} \text { VSS day }\right)\end{array}$ & $\begin{array}{l}\text { Denitrification rate } \\
\text { day })\end{array}$ & $\begin{array}{l}\mathrm{mg} \mathrm{NO}_{x}{ }^{-}-\mathrm{N} / \mathrm{g} \\
\mathrm{VSS}^{2}\end{array}$ \\
$\mathrm{C} / \mathrm{N}=3.4$ & $77.54 \pm 19.85$ & $27.59 \pm 11.51$ & $18.71 \pm 7.07$ \\
$\mathrm{C} / \mathrm{N}=5.4$ & $68.10 \pm 19.77$ & $78.59 \pm 36.13$ & $53.54 \pm 26.10$ \\
$\mathrm{C} / \mathrm{N}=7.5$ & $50.70 \pm 13.97$ & $81.87 \pm 61.76$ & $83.58 \pm 38.13$ \\
\hline
\end{tabular}

denitrification rate and retention time of the section. The retention times were 2.8 and $1.4 \mathrm{~h}$ for the anoxic and anaerobic sections, respectively. The $\mathrm{NO}_{\mathrm{x}}{ }^{-} \mathrm{-N}$ removal amounts in the anaerobic and anoxic sections were $314.5 \pm 131.3$ and $426.7 \pm 161.2 \mathrm{mg} /$ day, $895.9 \pm 411.8$ and $1220.6 \pm 595.0 \mathrm{mg} /$ day, and $933.3 \pm 704.1$ and $1905.7 \pm 869.4 \mathrm{mg} / \mathrm{L}$ under the influent $\mathrm{C} / \mathrm{N}$ ratios of $3.4,5.4$, and 7.5, respectively. This result indicated the denitrification reactions occurred primarily in the anoxic section, although a relatively high reaction rate was observed in the anaerobic section.

In addition, heterotrophic microorganisms could decrease the TN concentration by assimilating inorganic nitrogen, which is a potential approach for nitrogen removal in the anoxic section (Yan et al. 2016). At an elevated influent $\mathrm{C} / \mathrm{N}$ ratio, adequate organic matter enhanced the assimilation of microorganisms. Thus, with the influent $\mathrm{C} / \mathrm{N}$ ratio increased, the nitrification rate in the oxic section decreased (Table 4), and $\mathrm{COD}$ and $\mathrm{NH}_{4}{ }^{+}-\mathrm{N}$ showed higher removal effects (Fig. 3).

\section{$\mathrm{N}_{2} \mathrm{O}$ generation and emissions under different $\mathrm{C} / \mathrm{N}$ ratios}

Table 5 shows the $\mathrm{N}_{2} \mathrm{O}$ emissions and generation amount in each tank of the $\mathrm{A}^{2} \mathrm{O}$ system under different $\mathrm{C} / \mathrm{N}$ ratios. $\mathrm{N}_{2} \mathrm{O}$ emissions were calculated according to Eqs. (1)-(3), and the generation amount was calculated using Eqs. (4)-(7). The comparison of $\mathrm{N}_{2} \mathrm{O}$ emission between this study and other researchers was showed in Table 6 . The activities of the three key denitrifying enzymes, Nar, Nir, and Nos, in the anoxic section are shown in Fig. 4.

Several researchers have studied the effect of $\mathrm{C} / \mathrm{N}$ ratio on $\mathrm{N}_{2} \mathrm{O}$ emission in different wastewater treatment processes. Results showed a huge variation in the fraction of nitrogen that was emitted as $\mathrm{N}_{2} \mathrm{O}$ (Table 6). The $\mathrm{N}_{2} \mathrm{O}$ conversion ratio of this work was at a low level compared with others. In this treatment process, $\mathrm{N}_{2} \mathrm{O}$ emissions and generation, as well as the total $\mathrm{N}_{2} \mathrm{O}-\mathrm{N}$ conversion ratio, decreased distinctly as the influent $\mathrm{C} / \mathrm{N}$ ratio increased. Due to dissolved $\mathrm{N}_{2} \mathrm{O}$ could be brought by internal recycle liquid, sludge recycle liquid, and wastewater flow between units of the treatment process, $\mathrm{N}_{2} \mathrm{O}$ generation and emissions usually processed in different unit (Yan et al. 2014; Park et al. 2000). In this study, $\mathrm{N}_{2} \mathrm{O}$ emissions were primarily from the oxic section, as 59.56, 53.51, and $55.03 \%$ of the totals were emitted from this unit under the $\mathrm{C} / \mathrm{N}$ ratios of 3.4, 5.4, and 7.5, respectively. The anoxic and anaerobic sections generated the most $\mathrm{N}_{2} \mathrm{O}$ under the three influent modes (Table 5), but much lower emissions were observed in these two units. This was ascribed to the mechanical aeration and stirring in the oxic section, which promoted the stripping of the dissolved $\mathrm{N}_{2} \mathrm{O}$ from the liquid by diffusion (Czepiel et al. 1995).

$\mathrm{N}_{2} \mathrm{O}$ can be generated in both nitrification and denitrification processes (Kampschreur et al. 2009). In this study, $\mathrm{N}_{2} \mathrm{O}$ was generated mainly from the denitrification process in the anaerobic and anoxic tanks (Table 5). $\mathrm{N}_{2} \mathrm{O}$ is an intermediate in the denitrification process, lacking for electron donor of carbon source often result in incomplete denitrification which can lead to $\mathrm{N}_{2} \mathrm{O}$ generation. The $\mathrm{NO}_{2}{ }^{-}{ }^{-} \mathrm{N}$ and $\mathrm{NO}_{3}{ }^{-}-\mathrm{N}$ concentrations in the anaerobic and anoxic sections reflected the status of the denitrification processes (Fig. 3). When the influent $\mathrm{C} / \mathrm{N}$ ratio was 3.4 , denitrification reactions hardly occurred, which was reflected by the relative high $\mathrm{NO}_{3}{ }^{-} \mathrm{N}$ and low $\mathrm{NO}_{2}{ }^{-} \mathrm{N}$ concentrations. Under the $\mathrm{C} / \mathrm{N}$ ratios of 5.4 and 7.5, denitrification increased but incomplete denitrification also existed, as the $\mathrm{NO}_{3}{ }^{-} \mathrm{N}$ concentration decreased in the

Table $5 \quad \mathrm{~N}_{2} \mathrm{O}$ emission and generation in each unit of $\mathrm{A}^{2} \mathrm{O}$ process under different influent $\mathrm{C} / \mathrm{N}$ ratios

\begin{tabular}{lllll}
\hline & & $\mathrm{C} / \mathrm{N}=3.4$ & $\mathrm{C} / \mathrm{N}=5.4$ & $\mathrm{C} / \mathrm{N}=7.5$ \\
\hline Emission & Anaerobic section $(\mathrm{mg} / \mathrm{L})$ & $(12.87 \pm 7.41) \times 10^{-2}$ & $(1.26 \pm 0.90) \times 10^{-2}$ & $(0.85 \pm 0.79) \times 10^{-2}$ \\
& Anoxic section $(\mathrm{mg} / \mathrm{L})$ & $(12.14 \pm 7.30) \times 10^{-2}$ & $(1.32 \pm 1.21) \times 10^{-2}$ & $(0.51 \pm 0.46) \times 10^{-2}$ \\
& Oxic section $(\mathrm{mg} / \mathrm{L})$ & $(38.20 \pm 6.88) \times 10^{-2}$ & $(3.28 \pm 1.65) \times 10^{-2}$ & $(1.75 \pm 1.23) \times 10^{-2}$ \\
& Secondary sedimentation tank $(\mathrm{mg} / \mathrm{L})$ & $(0.93 \pm 0.46) \times 10^{-2}$ & $(0.27 \pm 0.05) \times 10^{-2}$ & $(0.07 \pm 0.02) \times 10^{-2}$ \\
& Total $\mathrm{N}_{2} \mathrm{O}$ emission $(\mathrm{mg} / \mathrm{L})$ & $(64.14 \pm 16.45) \times 10^{-2}$ & $(6.13 \pm 2.24) \times 10^{-2}$ & $(3.18 \pm 1.23) \times 10^{-2}$ \\
Generation & Anaerobic section $(\mathrm{mg} / \mathrm{L})$ & $(18.29 \pm 9.53) \times 10^{-2}$ & $(1.42 \pm 1.06) \times 10^{-2}$ & $(0.94 \pm 0.56) \times 10^{-2}$ \\
& Anoxic section $(\mathrm{mg} / \mathrm{L})$ & $(25.06 \pm 12.03) \times 10^{-2}$ & $(2.54 \pm 1.77) \times 10^{-2}$ & $(1.39 \pm 0.65) \times 10^{-2}$ \\
& Oxic section $(\mathrm{mg} / \mathrm{L})$ & $(16.76 \pm 7.15) \times 10^{-2}$ & $(1.32 \pm 0.77) \times 10^{-2}$ & $(0.67 \pm 0.26) \times 10^{-2}$ \\
& Secondary sedimentation tank $(\mathrm{mg} / \mathrm{L})$ & $(9.89 \pm 4.73) \times 10^{-2}$ & $(1.37 \pm 0.60) \times 10^{-2}$ & $(0.33 \pm 0.24) \times 10^{-2}$ \\
& Total $\mathrm{N}_{2} \mathrm{O}$ generation $(\mathrm{mg} / \mathrm{L})$ & $(70.00 \pm 18.47) \times 10^{-2}$ & $(6.65 \pm 1.96) \times 10^{-2}$ & $(3.33 \pm 0.74) \times 10^{-2}$ \\
& $\mathrm{~N}_{2} \mathrm{O}-\mathrm{N}$ conversion & & & 0.12 \\
\hline
\end{tabular}


Table 6 Comparison of $\mathrm{N}_{2} \mathrm{O}$ emission between this study and other researchers

\begin{tabular}{|c|c|c|c|c|}
\hline Type of process & $\begin{array}{l}\mathrm{C} / \mathrm{N} \\
\text { ratio }\end{array}$ & $\mathrm{N}_{2} \mathrm{O}$ emission & Remarks & Reference \\
\hline $\mathrm{A} / \mathrm{A} / \mathrm{O}$ & $\begin{array}{l}3.5 \\
7.5 \\
10.8\end{array}$ & $\begin{array}{l}9.18 \% \text { of } \mathrm{TN}_{\text {removed }} \\
0.41 \% \text { of } \mathrm{TN}_{\text {removed }} \\
0.04 \% \text { of } \mathrm{TN}_{\text {removed }}\end{array}$ & Real municipal wastewater & Ren et al. (2015) \\
\hline $\begin{array}{l}\text { Biological nitrogen removal } \\
\text { process }\end{array}$ & $\begin{array}{l}2.4-3.5 \\
5.0-5.5\end{array}$ & $\begin{array}{l}20-30 \% \text { of } \mathrm{TN}_{\mathrm{load}} \\
\text { Less than } 1 \% \text { of } \mathrm{TN}_{\mathrm{load}}\end{array}$ & $\begin{array}{l}\text { High-strength wastewater } \\
\left(1700-1800 \mathrm{mg} \mathrm{NH}_{4}^{+}-\mathrm{N} / \mathrm{L} \text { and } 4100-9900 \mathrm{mg}\right. \\
\text { COD/L) }\end{array}$ & Itokawa et al. (2001) \\
\hline $\begin{array}{l}\text { Nitrogen removal process } \\
\text { of swine wastewater } \\
\text { treatment }\end{array}$ & $\begin{array}{l}2.6 \\
4.5\end{array}$ & $\begin{array}{l}17.70 \% \text { of } \mathrm{TN}_{\text {load }} \\
1.71 \% \text { of } \mathrm{TN}_{\text {load }}\end{array}$ & $\begin{array}{l}\text { Swine waste was added to adjust } \\
\text { the } \mathrm{C} / \mathrm{N} \text { ratio }\end{array}$ & Kishida et al. (2004) \\
\hline Denitrification process & $2.5-5.6$ & $\begin{array}{l}0.005 \%-0.5 \% \text { of } \\
\mathrm{TN}_{\text {removed }}\end{array}$ & & $\begin{array}{l}\text { Chung and Chung } \\
(2000)\end{array}$ \\
\hline $\mathrm{A} / \mathrm{A} / \mathrm{O}$ & $\begin{array}{l}3.4 \\
5.4 \\
7.5\end{array}$ & $\begin{array}{l}2.23 \% \text { of } \mathrm{TN}_{\text {removed }} \\
0.12 \% \text { of } \mathrm{TN}_{\text {removed }} \\
0.05 \% \text { of } \mathrm{TN}_{\text {removed }}\end{array}$ & Real municipal wastewater & This study \\
\hline
\end{tabular}

anaerobic and anoxic sections and relatively high $\mathrm{NO}_{2}{ }^{-} \mathrm{N}$ concentrations were observed. Moreover, the activities of Nar, Nir, and Nos in the anoxic section, which were positively correlated with denitrification rate and $\mathrm{TN}$ removal rate, obviously increased as the $\mathrm{C} / \mathrm{N}$ ratio increased. As a result, as the carbon source increased in the influent, the denitrification increased and $\mathrm{N}_{2} \mathrm{O}$ generation decreased observably (Tables 4 and 5). The decrease in ORP in anaerobic and anoxic tanks also reflected that denitrification reactions were enhanced with the increased carbon source (Table 3). Ren et al. (2015) and Itokawa et al. (2001) also found a similar phenomenon in aerobic treatment processes and a lab-scale sequencing batch reactor (SBR), respectively.

$\mathrm{N}_{2} \mathrm{O}$ generated from nitrification processes have been observed in several full-scale WWTPs (Yan et al. 2014; Ahn et al. 2010; Foley et al. 2010), which was also found in this study. Of the total $\mathrm{N}_{2} \mathrm{O}$ production, 23.94, 19.85, and $20.12 \%$ were generated from the oxic section under the $\mathrm{C} / \mathrm{N}$ ratios of $3.4,5.4$, and 7.5, respectively. Moreover, the $\mathrm{N}_{2} \mathrm{O}$ generation from this process decreased from $(16.76 \pm 7.15) \times 10^{-2}$ to $(0.67 \pm 0.26) \times 10^{-2} \mathrm{mg} / \mathrm{L}$ as the $\mathrm{C} / \mathrm{N}$ ratio increased from

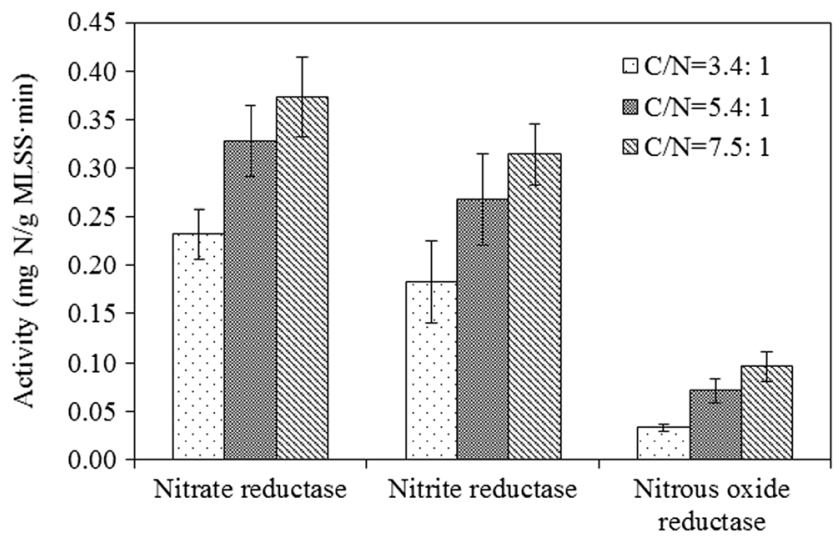

Fig. 4 Nar, Nir, and Nor activities in the anoxic section
3.4 to 7.5. During the nitrification process, when $\mathrm{N}_{2} \mathrm{O}$ was not an intermediate product, nitrifier denitrification by AOB was considered the primary $\mathrm{N}_{2} \mathrm{O}$ production source (Kampschreur et al. 2009). Even though $\mathrm{N}_{2} \mathrm{O}$ production in pure culture experiments has been observed from chemical reactions of unstable biological intermediates (Colliver and Stephenson 2000), this pathway is of minor importance in active sludge systems (Wunderlin et al. 2012). Consequently, the $\mathrm{N}_{2} \mathrm{O}$ generation from the nitrifier denitrification pathway also showed negative correlation with the influent $\mathrm{C} / \mathrm{N}$ ratio.

A portion of $\mathrm{N}_{2} \mathrm{O}$ generation by the treatment system originated from the secondary sedimentation tank by the denitrification pathway, which was inferred by the difference in TN concentration between the secondary sedimentation tank and the oxic section. High $\mathrm{NO}_{\mathrm{x}}{ }^{-} \mathrm{N}$, low DO, and insufficient $\mathrm{COD}$ were also detected in this unit (Table 3 and Fig. 3), which all benefited $\mathrm{N}_{2} \mathrm{O}$ generation (Kampschreur et al. 2009).

\section{Microbial community characteristics under different $\mathbf{C} / \mathbf{N}$ ratios}

Activated sludge was taken from the $\mathrm{A}^{2} \mathrm{O}$ process after continuous operation for 2 months. The FISH images from the oxic section of the process are shown in Fig. 5. To quantify the microorganisms' ability to convert $\mathrm{N}_{2} \mathrm{O}$ to $\mathrm{N}_{2}$, a qPCR assay targeting the nos $Z$ gene was carried out. The nos $Z$ gene copy numbers in the anoxic section under different influent $\mathrm{C} / \mathrm{N}$ ratios are presented in Fig. 6.

The characterization of the microbial communities in the oxic section revealed that $\mathrm{AOB}$ accounted for $(8.42 \pm 3.65)$, $(4.93 \pm 2.27)$, and $(3.61 \pm 1.66) \%$ and NOB accounted for $(10.38 \pm 4.12),(5.79 \pm 2.08)$, and $(4.67 \pm 1.62) \%$, under the influent $\mathrm{C} / \mathrm{N}$ ratios of 3.4, 5.4, and 7.5, respectively (accounting for the domain bacteria). This result showed that with the 
Fig. 5 Microscope images of sludge from the oxic section of the $\mathrm{A}_{2} \mathrm{O}$ process as visualized by FISH. A1-A3, B1-B3, and C1$\mathrm{C} 3$ were the images under the influent $\mathrm{C} / \mathrm{N}$ ratio of $3.4,5.4$, and 7.4 , respectively. Domain bacteria that were dyed DAPI displayed red, the green pixels in images represented NOB, and the yellow pixels represented $\mathrm{AOB}$
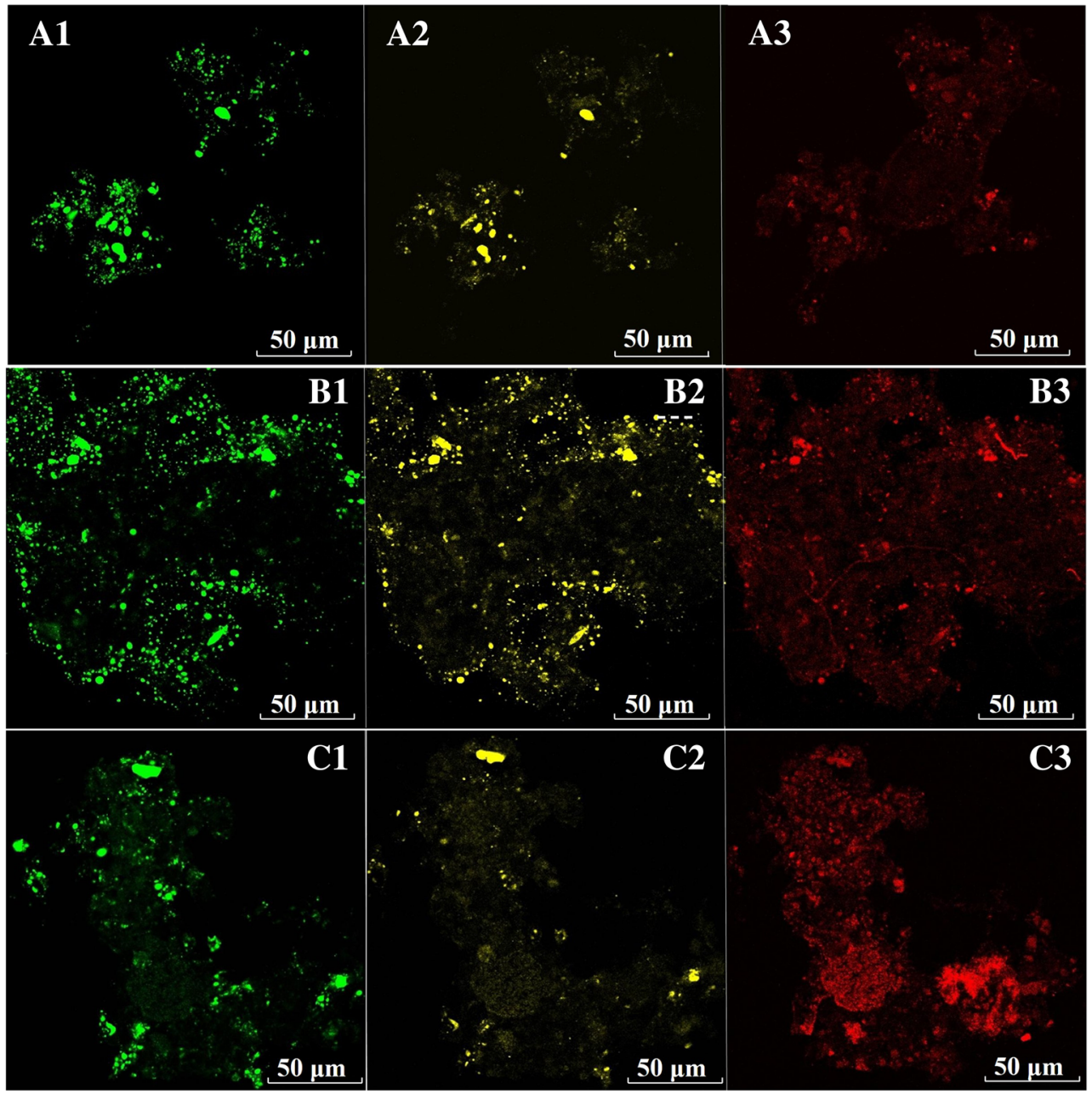

increased carbon source from the influent, the relative abundances of $\mathrm{AOB}$ and NOB in the systems decreased, as did the nitrification rate observed in the oxic section (Table 4).

Compared with aerobic heterotrophs, the growth rate and competitive ability for oxygen of autotrophic nitrifying bacteria are lower; therefore, nitrification is difficult to maintain in WWTPs (Lee et al. 2011). Moreover, AOB are known to

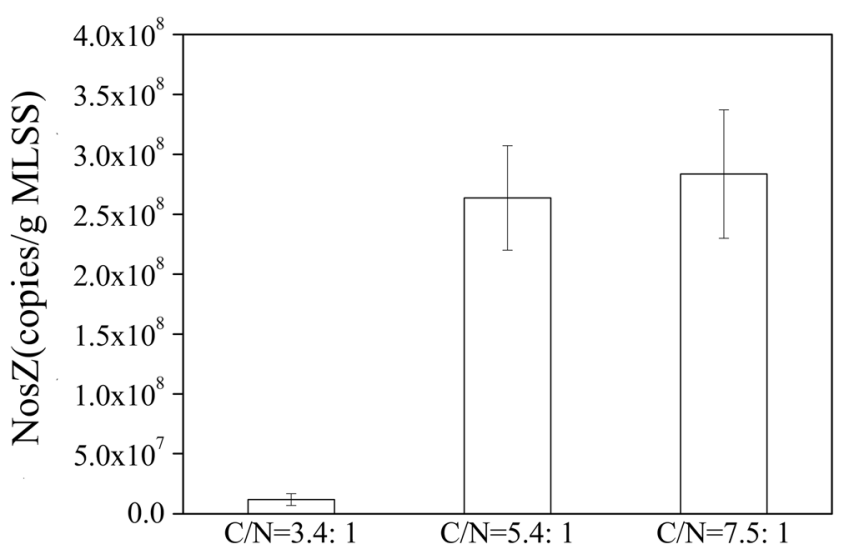

Fig. 6 NosZ gene copy numbers in the anoxic section under different influent $\mathrm{C} / \mathrm{N}$ ratios produce $\mathrm{N}_{2} \mathrm{O}$ via nitrifier denitrification under oxic conditions (Colliver and Stephenson 2000). This decrease in relative abundance of AOB was probably the main reason for the reduction in $\mathrm{N}_{2} \mathrm{O}$ generation from the oxic section as the influent $\mathrm{C} / \mathrm{N}$ ratio increased.

The nos $Z$ gene, which encodes Nos, is well known for catalyzing the reduction from $\mathrm{N}_{2} \mathrm{O}$ to $\mathrm{N}_{2}$ and usually has been employed for detecting denitrifier-specific DNA (Zhu and Chen et al. 2011). In BNR processes, the existence of the nos $Z$ gene implies that the treatment biosystem has the ability to convert $\mathrm{N}_{2} \mathrm{O}$ to $\mathrm{N}_{2}$ (Lu et al. 2014). In this study, the nos $Z$ gene copy numbers markedly increased as the $\mathrm{C} / \mathrm{N}$ ratio increased from 3.4 to 7.5 (Fig. 6), revealing the importance of the influent nutritional condition for nosZ-containing bacteria. In addition, the nos $Z$ gene copy numbers showed a positive correlation with the activities of the denitrifying enzymes and denitrification effect but negative correlation with $\mathrm{N}_{2} \mathrm{O}$ generation. The increase in nos $Z$ gene copy number means the denitrification ability of $\mathrm{N}_{2} \mathrm{O}$ increased (Yan et al. 2016). Hence, nitrogen removal and $\mathrm{N}_{2} \mathrm{O}$ emissions reduction effects were simultaneously improved as the $\mathrm{C} / \mathrm{N}$ ratio increased in this treatment process. 
The removal of pollutants and $\mathrm{N}_{2} \mathrm{O}$ generation from wastewater treatment is determined primarily by the microorganismal community composition and activity of the activated sludge (Kampschreur et al. 2009). Sun et al. (2012) observed how the changes in initial biodegradable COD/ $\mathrm{NO}_{3}{ }^{-}-\mathrm{N}$ ratio affected the nitrate reduction rate and the denitrifier microbial communities. Zhu and Chen (2011) increased nos $Z$ gene copy numbers by using waste-activated sludge alkaline fermentation liquid as the synthetic wastewater-carbon source in an anaerobic-aerobic treatment process. As a result, the $\mathrm{N}_{2} \mathrm{O}$ generation decreased by $68.7 \%$ and the removal efficiencies of TP and TN also improved. In an $\mathrm{A}^{2} \mathrm{O}$ wastewater treatment process, Yan et al. (2016) found an increase in internal recycle ratio from 100 to $300 \%$ could decrease the nos $Z$ gene copy numbers dramatically, which led to an increase in $\mathrm{N}_{2} \mathrm{O}$ production. As shown from this work, changes in influent $\mathrm{C} / \mathrm{N}$ ratio influenced the relative abundances of $\mathrm{AOB}$ and $\mathrm{NOB}$ and the nos $Z$ gene copy numbers, which resulted in $\mathrm{N}_{2} \mathrm{O}$ generation variation. These results reveal that in wastewater treatment systems, appropriate influent $\mathrm{C} / \mathrm{N}$ conditions can enhance nitrogen removal efficiency and simultaneously decrease $\mathrm{N}_{2} \mathrm{O}$ generation.

\section{Conclusions}

Changes in influent $\mathrm{C} / \mathrm{N}$ ratio showed obvious effects on $\mathrm{BNR}$ and $\mathrm{N}_{2} \mathrm{O}$ generation in the $\mathrm{A}^{2} \mathrm{O}$ treatment process. As the influent $\mathrm{C} / \mathrm{N}$ ratio increased from 3.4 to 7.5 , the $\mathrm{TN}$ removal rate increased from 21.69 to $61.56 \%, \mathrm{~N}_{2} \mathrm{O}$ generation in both nitrification and denitrification processes decreased, and the $\mathrm{N}_{2} \mathrm{O}$ conversion ratio of the treatment system decreased evidently from 2.23 to $0.05 \%$. The primarily cause of this phenomenon was the variation of microbial community, as increased influent $\mathrm{C} / \mathrm{N}$ ratio reduced the relative abundance of $\mathrm{AOB}$ and $\mathrm{NOB}$ and promoted the development of nosZcontaining bacteria.

Acknowledgments This work was supported by the National Natural Science Foundation of China (NSFC China) (51408199) and the Key Science and Technology Program of Henan Province, People's Republic of China (162102310096).

\section{References}

Ahn JH, Kim S, Park H, Rahm B, Pagilla K, Chandran K (2010) $\mathrm{N}_{2} \mathrm{O}$ emissions from activated sludge processes, 2008-2009: results of a national monitoring survey in the United States. Environ Sci Technol 44:4505-4511

CEPB (2004) Standard methods for examination of water and wastewater (2002), 4th edn. Chinese Environmental Science Press, Beijing

Chon K, Chang JS, Lee E, Lee J, Ryu J, Cho J (2011) Abundance of denitrifying genes coding for nitrate (narG), nitrite (nirS), and nitrous oxide $(\operatorname{nos} Z)$ reductases in estuarine versus wastewater effluent-fed constructed wetlands. Ecol Eng 37:64-69

Chung YC, Chung MS (2000) BNP test to evaluate the influence of $\mathrm{C} / \mathrm{N}$ ratio on $\mathrm{N}_{2} \mathrm{O}$ production in biological denitrification. Water Sci Technol 42:23-27

Colliver BB, Stephenson T (2000) Production of nitrogen oxide and dinitrogen oxide by autotrophic nitrifiers. Biotechnol Adv 18:219 232

Czepiel P, Crill P, Harriss R (1995) Nitrous oxide emissions from municipal wastewater treatment. Environ Sci Technol 29:2352-2356

Foley J, de Haas D, Yuan ZG, Lant P (2010) Nitrous oxide generation in full-scale biological nutrient removal wastewater treatment plants. Water Res 44:831-844

Han Y, Liu J, Guo X, Li L (2012) Micro-environment characteristics and microbial communities in activated sludge flocs of different particle size. Bioresour Technol 124:252-258

Hanaki K, Hong Z, Matsuo T (1992) Production of nitrous oxide gas during denitrification of wastewater. Water Sci Technol 26:10271036

He Q, Zhu YY, Fan LL, Ai HN, Huangfu XL, Chen M (2016) Effects of $\mathrm{C} / \mathrm{N}$ ratio on nitrous oxide production from nitrification in a labscale biological aerated filter reactor. Water Sci Technol. https:// doi.org/10.2166/wst.2016.447

Hu Z, Zhang J, Xie H, Liang S, Li S (2013) Minimization of nitrous oxide emission from anoxic-oxic biological nitrogen removal process: effect of influent $\mathrm{COD} / \mathrm{NH}_{4}{ }^{+}$ratio and feeding strategy. J Biosci Bioeng 115:272-278

Hynes, Knowles R (1984) Production of nitrous-oxide by Nitrosomonas europaea - effects of acetylene, $\mathrm{pH}$, and oxygen. Can J Microbiol 30:1397-1404

Itokawa H, Hanaki K, Matsuo T (2001) Nitrous oxide production in highloading biological nitrogen removal process under low $\mathrm{COD} / \mathrm{N}$ ratio condition. Water Res 35:657-664

Kampschreur MJ, van der Star WRL, Wielders HA, Mulder JW, Jetten MSM, van Loosdrecht MCM (2008) Dynamics of nitric oxide and nitrous oxide emission during full-scale reject water treatment. Water Res 42:812-826

Kampschreur MJ, Temmink H, Kleerebezem R, Jetten MSM, van Loosdrecht MCM (2009) Nitrous oxide emission during wastewater treatment. Water Res 43:4093-4103

Kimochi Y, Inamori Y, Mizuochi M, Xu KQ, Matsumura M (1998) Nitrogen removal and $\mathrm{N}_{2} \mathrm{O}$ emission in a full-scale domestic wastewater treatment plant with intermittent aeration. J Ferment Bioeng 86:202-206

Kishida N, Kim JH, Kimochi Y, Nishimura O, Sasaki H, Sudo R (2004) Effect of $\mathrm{C} / \mathrm{N}$ ratio on nitrous oxide emission from swine wastewater treatment process. Water Sci Technol 49:359-365

Kool DM, Wrage N, Zechmeister-Boltenstern S, Pfeffer M, Brus D, Oenema O, Van Groenigen JW (2010) Nitrifier denitrification can be a source of $\mathrm{N}_{2} \mathrm{O}$ from soil: a revised approach to the dual-isotope labelling method. Eur J Soil Sci 61:759-772

Kristjansson JK, Hollocher TC (1980) First practical assay for soluble nitrous oxide reductase of denitrifying bacteria and a partial kinetic characterization. J Biol Chem 255:704-707

Lee DS, Jeon CO, Park JM (2011) Biological nitrogen removal with enhanced phosphate uptake in a sequencing batch reactor using single sludge system. Water Res 35:3968-3976

Li P, Wang Y, Zuo J, Wang R, Zhao J, Du Y (2017) Nitrogen removal and $\mathrm{N}_{2} \mathrm{O}$ accumulation during hydrogenotrophic denitrification: influence of environmental factors and microbial community characteristics. Environ Sci Technol 51:870-879

Lu HJ, Chandran K, Stensel D (2014) Microbial ecology of denitrification in biological wastewater treatment. Water Res 64:237-254

Lv Y, Ju K, Sun T, Wang L, Miao R, Liu T, Wang X (2016) Effect of the dissolved oxygen concentration on the $\mathrm{N}_{2} \mathrm{O}$ emission from an 
autotrophic partial nitritation reactor treating high-ammonium wastewater. Int Biodeter Biodegr 114:209-215

Mannina G, Cosenza A, Di Trapani D, Laudicina VA, Morici C, Odegaard H (2016) Nitrous oxide emissions in a membrane bioreactor treating saline wastewater contaminated by hydrocarbons. Bioresour Technol 219:289-297

Marques R, Rodriguez-Caballero A, Oehmen A, Pijuan M (2016) Assessment of online monitoring strategies for measuring $\mathrm{N}_{2} \mathrm{O}$ emissions from full-scale wastewater treatment systems. Water Res 99:171-179

Park KY, Inamori Y, Mizuochi M, Ahn KH (2000) Emission and control of nitrous oxide from a biological wastewater treatment system with intermittent aeration. J Biosci Bioeng 90:247-252

Ren YG, Wang JH, Xu L, Liu C, Zong RQ, Yu JL, Liang S (2015) Direct emissions of $\mathrm{N}_{2} \mathrm{O}, \mathrm{CO}_{2}$, and $\mathrm{CH}_{4}$ from $\mathrm{A} / \mathrm{A} / \mathrm{O}$ bioreactor systems: impact of influent $\mathrm{C} / \mathrm{N}$ ratio. Environ Sci Pollut R 22:8163-8173

Ribera-Guardia A, Marques R, Arangio C, Carvalheira M, Oehmen A, Pijuan M (2016) Distinctive denitrifying capabilities lead to differences in $\mathrm{N}_{2} \mathrm{O}$ production by denitrifying polyphosphate accumulating organisms and denitrifying glycogen accumulating organisms. Bioresour Technol 219:106-113

Rodriguez-Caballero A, Aymerich I, Marques R, Poch M, Pijuan M (2015) Minimizing $\mathrm{N}_{2} \mathrm{O}$ emissions and carbon footprint on a fullscale activated sludge sequencing batch reactor. Water Res 2015(71):1-10

Sun FQ, Wu SW, Liu JJ, Li B, Chen YX, Wu WX (2012) Denitrification capacity of a landfilled refuse in response to the variations of COD/ $\mathrm{NO}_{3}{ }^{-} \mathrm{N}$ in the injected leachate. Bioresour Technol 103:109-115

Wang JH, Zhang J, Wang J, Qi PY, Ren YG, Hu Z (2011a) Nitrous oxide emissions from a typical northern Chinese municipal wastewater treatment plant. Desalin Water Treat 32:145-152

Wang YY, Geng JJ, Guo G, Wang C, Liu SH (2011b) $\mathrm{N}_{2} \mathrm{O}$ production in anaerobic/anoxic denitrifying phosphorus removal process: the effects of carbon sources shock. Chem Eng J 172:999-1007
Wang YY, Lin XM, Zhou D, Ye L, Han HC, Song CK (2016) Nitric oxide and nitrous oxide emissions from a full-scale activated sludge anaerobic/anoxic/oxic process. Chem Eng J 289:330-340

Wei D, Zhang K, Ngo HH, Guo W, Wang S, Li J, Han F, Du B, Wei Q (2017) Nitrogen removal via nitrite in a partial nitrification sequencing batch biofilm reactor treating high strength ammonia wastewater and its greenhouse gas emission. Bioresour Technol 230:49-55

Wunderlin P, Mohn J, Joss A, Emmenegger L, Siegrist H (2012) Mechanisms of $\mathrm{N}_{2} \mathrm{O}$ production in biological wastewater treatment under nitrifying and denitrifying conditions. Water Res 46:10271037

Xie T, Wang C (2011) Impact of different factors on greenhouse gas generation by wastewater treatment plants in China. Water Res Environ Protection 2:1448-1451

Yan X, Li L, Liu J (2014) Characteristics of greenhouse gas emission in three full-scale wastewater treatment processes. J Environ Sci China 26:256-263

Yan X, Hang Y, Li Q, Sun J, Su X (2016) Impact of internal recycle ratio on nitrous oxide generation from an aerobic/anoxic/oxic biological nitrogen removal process. Biochem Eng J 106:11-18

Zhang QH, Yang WN, Ngo HH, Guo WS, Jin PK, Dzakpasu M, Yang SJ, Wang Q, Wang XC, Ao D (2016a) Current status of urban wastewater treatment plants in China. Environ Int 92-93:11-22

Zhang X, Wang X, Zhang J, Huang X, Wei D, Lan W, Hu Z (2016b) Reduction of nitrous oxide emissions from partial nitrification process by using innovative carbon source (mannitol). Bioresour Technol 218:789-795

Zhu XY, Chen YG (2011) Reduction of $\mathrm{N}_{2} \mathrm{O}$ and $\mathrm{NO}$ generation in anaerobic-aerobic (low dissolved oxygen) biological wastewater treatment process by using sludge alkaline fermentation liquid. Environ Sci Technol 45:2137-2143 